SCIENCE AND VALUES 
Pittsburgh Series in

Philosophy and History

of Science

Series Editors:

Adolf Grünbaum

Larry Laudan

Nicholas Rescher

Wesley C. Salmon 


\section{SCIENCE AND VALUES}

The Aims of Science and Their Role in Scientific Debate

\section{Larry Laudan}

University of California Press

Berkeley Los Angeles London 


\section{University of California Press \\ Berkeley and Los Angeles, California \\ University of California Press, Ltd. \\ London, England}

Copyright (C) 1984 by The Regents of the University of California

\section{Library of Congress Cataloging in Publication Data}

Laudan, Larry.

Science and values.

(Pittsburgh series in philosophy and history of science ; v. 11)

Bibliography: p. 141

Includes index.

1. Science-Philosophy. I. Title. II. Series. Q175.L295 1984

ISBN 0-520-05267-6 501

84-249

Printed in the United States of America

The paper used in this publication meets the minimum requirements of ANSI/NISO Z39.48-1992 (R 1997)

(Permanence of Paper). @)

This book is a print-on-demand volume. It is manufactured using toner in place of ink. Type and images may be less sharp than the same material seen in traditionally printed University of California Press editions. 
to my favorite geologist - who never forgot about hard rocks 
This page intentionally left blank 